\author{
MESSASH KASSAYE WOLDETSADIK, \\ Institute for Peace and Security Studies (IPSS) \\ Addis Ababa University, Addis Ababa (Ethiopia), \\ e-mail: messashkassaye@gmail.com, ORCID 0000-0003-3590-6198
}

\title{
CONFLICT ANALYSIS OF LIBERIA'S CIVIL WARS (1989-2003)
}

The given article presents the results of scientific research of a number of civil wars in Liberia from 1989 to 2003. The historiographical background is reviewed and the main scientific approaches to the analysis of civil war events are presented by the author. The author analyzes the historical background and prerequisites for the emergence of armed confrontation. In particular, the complex of reasons of historical and political nature, among which stands out: the artificial political traditions, introduced in the nineteenth century by the immigrants from the United States, the weakness of democratic institutions and the Liberian community as a whole. Appealing to the peculiarities of political development in the second half of the twentieth century, the author presents the confrontation between the various ethnic groups of Liberia. It is noted that the key factors of the unstability of the political system were: authoritarian management methods, high level of corruption, extremely low level of education, inefficient economy.

It is also emphasized that the policy of President William Tubman (1944-1971) was aimed at destroying the traditional socio-economic structure of the indigenous population. During William Tubman's presidency, discriminatory approaches and policies for replacing key posts were widely used exclusively by the American-Liberian elite. The "open door" policy for US capital, begun in the 1920s, has become even more significant by President William Tolbert, who has continued the policy of the predecessor.

In the late 1970s, the economic situation in the country began to deteriorate, and rising food prices have led to a series of mutiny throughout the country.

The peak of civil disobedience has become mass strikes, which led to the coup d'état of 1980 . During the events of 1980 , the regime of President William Tolbert was abolished. The authorities in the country went to one of the leaders of the ethnic group of Kran - Samuel Dow, who executed the president and the entire administrative elite. The second half of the 1980s was the time of transit of power and the replacement of key positions by representatives of the Kranes.

It was in events that tied to the formation of a new alliance of political forces represented by numerous representatives of the indigenous population, creating the greatest contradictions of the regime, which later added external actors - Sierra Leone and the United States. The complex of contradictions formed in the country and the interests of the participants of the conflict are visualized in two matrices, which reflect the author's concept of understanding the driving forces and the origins of a series of civil wars in Liberia.

Key words: conflict; civil war; conflict actors; conflict context; conflict dynamics; Liberia.

Research Analysis and Research Publications on this Issue

Literature on the context, causes, actors and dynamics of Liberia's civil wars is highlighted by numerous authors. While some focus on specific aspects of the armed conflict, others provide a holistic view (M. B. Akpan, N. Cook, P. Dennis, S. Dick, J. B. Galvanek, F. Gerdes, S. Herbert, G. K. Kieh, F. Kraaij). The researcher mainly uses secondary data from works of scholars who have extensive knowledge in the area.

Purpose

The major aim of this article is to carry out an in-depth analysis of Liberia's two civil wars through employing a conflict tree, conflict mapping and timeline to discuss the causes, actors and dynamics.

\section{Presenting the Main Materia}

1. Introduction. Context of the Civil Wars in Liberia Liberia is one of the post-conflict West African states that shares borders with Guinea on the north, the Atlantic Ocean to its south, Sierra Leone to the northwest and Cote d'Ivoire to the east. In addition to resources like iron ore, timber, diamonds, gold and rubber, the land is gifted with climate that is suitable for farming. However, the state has a delicate economy, fragile democracy and troubles with ethnically diverse population.

Literature on the country's political, economic and social dynamics implies that the two civil wars fought from 1989 up to 2003 are the core reasons for the fragile situation in Liberia. Those outbreaks brought devastation not only for the Liberians but also for neighboring countries because 
of putting up with refugees due to the armed conflict. For this reason, understanding the conflict context along with the causes, actors and dynamics deems appropriate.

Today's Liberia, historically, known as the Pepper Coast due to its abundant melegueta pepper grains was the land of native African tribes. In 1821 though, the American Colonization Society (ACS) established contact with indigenous leaders to discuss the possibility of obtaining land to settle freed slaves from America (Dick, 2003). As a result, freed slaves known as "the Americo-Liberians" began to arrive.

Even though the ACS entrance seems to alleviate the opposition of slaves in the United States, it established an exclusive state for settlers. Gerdes (2013: 16) argued that the main activities of ACS were concentrated on "securing land, organizing emigration, sending agents to rule the colony, and financing the supply of consumer goods supporting the early settlers." Those actions gave the settlers political and economic autonomy over the natives even after integration with indigenous community had been made through marriage (Dennis, 2006). They tried to stop any opposition of the natives by force and treaties were usually concluded in their favor (Galvanek, 2016).

After settlers' regime came to an end in 1980 with the killing of President Tolbert, the term of Samuel Doe and Charles Taylor could not conclude the history of autocracy that had been existing over a century. Ethnic favoritism and severe human right abuses were added to the already delicate political, economic and social dynamics of the country (Galvanek, 2016; Kraaij, 2015). Those internal issues coupled with the external factor led to the first (19891996) and the second (1997-2003) civil war of Liberia.

\section{Causes of the Civil Wars}

The fundamental causes for the first civil war include the autocratic rule of the Americo-Liberians, repressive regimes followed, ethnic bigotry and rampant corruption. In addition to failure of addressing the underlying roots of the first civil war, incomplete transitional processes after the first civil war caused the second civil war. It is important to note that external factors also played their role. These issues are discussed hereunder and illustrated in a conflict tree.

\section{The Americo-Liberian Rule}

The Americo-Liberian regime is one of the root causes of Liberian prolonged civil war due to its preferential and discriminatory policy by excluding indigenous communities. They changed the centralized, de-centralized and mixed socio-political organization of the indigenous population to a centralized one and assumed prominent positions in the executive, legislative and judiciary organs (Kieh, 2012).

The state was also dominated by one party, namely the True Whig Party. Some even contend there is a similarity between methods used by European colonial powers and those of the Americo-Liberians and consider their policy as "black imperialism" (Akpan, 1973). The "so say one, so say we all" law-making approach also gave ultimate power to the President at the time (Kieh, 2012). As soon as a bill forwarded by the President had been read, the legislator just proclaimed "so say one, so say we all" and it was passed through some channels to become a law (Kieh, 2012).

Autocracy was boldly manifested itself under the administration of Tubman (1944-1971) and Tolbert (19711980 ). Their term was marked by centralized administration, fearful security, misuse of public funds and unlimited presidential term (Galvanek, 2016). Due to that, settlers faced attacks from indigenous community over land possession, representation and trading among others (Kieh, 2012).

Economic-wise, the "Open Door" policy made foreign investors profitable while people at grassroots lives in destitute (Dick, 2003). US rubber and iron ore plants that prospered from the export of Liberia's raw materials and cheap local labor in exchange for loans and donations made the state economy dependent on foreign investment ${ }^{1}$.

Furthermore, indigenous communities were stigmatized. Since the Americo-Liberians appreciate the life of Westerners, they labeled the natives as "barbarians" and disregarded their culture and values which had existed well before 1821 (The Advocates for Human Rights, 2009; Akpan, 1973). The natives also oppose the political label "Americo-Liberians" due to its potential to abolish any chance of cultural and societal integration between them and settlers (Galvanek, 2016).

Repressive Rule of Doe and Taylor

The administration of Doe (1986-1990) and Taylor (1997-2003) succeeded in neither democratically reconstituting Liberia nor protecting human rights. Occasions for leaders of civil society, journalists, labor unions, students, opposing political parties and civilians to be intimidated, arrested, raped and forced to exile were many (Galvanek, 2016; Kieh, 2012, Dick, 2003)². The 1984 military invasion of the University of Liberia, mass killings of the Gio and Mano tribes in Doe's term, similar retribution attacks on the Krahn and Mandingo tribes after 1989 and recruitment of child soldiers under Taylor's term are notable cases.

\section{Ethnic Hegemony}

Ethnicity was not a big issue for the Liberians till Doe's term. As Galvanek (2016) puts it, his regime was typified by ethnic domination which favored the Krahn ethnic group where he had come from. The ethnic bigotry increased particularly following the assassination attempt on Doe organized by Thomas Quiwonkpa in 1985 who came from the Nimba County (Galvanek, 2016). The Doe's administration attacked the Gio and Mano ethnic groups in the Nimba province in retribution which furthered the hostility. The politicization of ethnicity also continued in Taylor's term. During the civil war years many people from the Krahn as well as Gio and Mano tribes were massacred. People from the Madingo tribes - foreign immigrants from Guinea were also victims during Taylor's regime because they had links with Samuel Doe (Kieh, 2009).

\section{Rampant Corruption}

Economic benefit became a motivation to seize and stay in power before and after 1989. During Tolbert's Presidency, the wealth of few higher government officials including the President was way higher than the state budget (The Advocates for Human Rights, 2009). The President also abused housing funds for lower income communities to build mansions for people at the ministerial level in 1970 (The Advocates for Human Rights, 2009). Low salaries of civil servants and lack of a property right also pushed government employees to misuse public funds and properties (The Advocates for Human Rights, 2009). Doe and Taylor were also openly criticized for illicit enrichment which resulted in departure of foreign companies from Liberia, huge economic loss at the national level and left ordinary citizens with deprivation (Galvanek, 2016; The Advocates for Human Rights, 2009; Dick, 2003).

\footnotetext{
1 The Open Door Policy of Liberia: An Economic History of Modern Liberia (1847-1977). Available at: http://www.liberiapastandpresent.org

2 Human Rights Watch Reports on Liberian Civil War. Available at: http://www.hrw.org/reports/world/liberia-pubs.php
} 


\section{Failure of Transitional Process}

The main post first civil war transitional activities in Liberia were Disarmament, Demobilization, Rehabilitation and Re-integration (DDRR) and the Security Sector Reform (SSR). However, their execution was incomplete (Herbert, 2014; Kieh, 2009). The fact that short time was allotted for the disarmament exercise, absence of special camps to encamp ex-combatants, lack of education and training for ex-combatants to learn new skills and the absence of programs to create awareness to both excombatants and the community that re-integration was taking place made the DDRR symbolic (Herbert, 2014; Kieh, 2009). Due to the above, ex-combatants who had nothing to do were engaged in abusing drugs, common crimes and even re-joined warring factions.

On the other hand, once Taylor had assumed Presidency in 1997, he rejected the Abuja II Peace accord that had finished the first civil war and opened doors for restructuring transparent security forces (Herbert, 2014; $K i e h, 2009)$. Hence, the state featured unprofessional and brutal military forces that had been terrorizing and traumatizing the society till 2003.

External Factors

The governments in Liberia formed an alliance with international and regional actors at different points in time, which directly or indirectly contributed to the civil wars. For instance, the involvement of foreign investors in rubber, iron ore and other trading activities and departure of the
US after the cold war added significantly to economic deprivation (Dick, 2003). Withholding of development assistance by the EU and the US during the second civil war also exacerbated the warfare ${ }^{3}$.

Regionally; Doe's administration formed an alliance with the Sierra Leon government, which involved assistance to the Krahn and Mandingo ethnic groups in escaping Taylor's army and regrouping to launch an attack on the Taylor led-National Patriotic Front of Liberia (NPFL) during the first civil war (Dick, 2003). On the other hand, the Sierra Leone government contributed to the withholding of aid to Liberia by international community due to Taylor's support of the Revolutionary United Front (RUF) - a rebel group in Sierra Leone ${ }^{4}$.

President Taylor also formed an alliance with Burkina Faso, Gambia and Cote d'Ivoire. The Antiterrorist Unit (ATU) that was caught up in various criminal acts like looting and murder as of 2002 was also composed of the Special Forces from Burkina Faso and Gambia ${ }^{5}$. Even though Cote d'Ivoire was complicit in allowing Taylor to launch an attack from its borders in 1989, it denied access to Liberian refugees in 1996 for security reasons (Dick, 2003). The Government of Ghana also denied access to the Liberians for similar reason (Dick, 2003).

Even though the Economic Community of West Africa (ECOWAS) sent a force named the ECOWAS Monitoring Group (ECOMOG) in 1990 to intervene in the Liberian civil war, the force was underpaid. Dick (2003: 9) mentioned

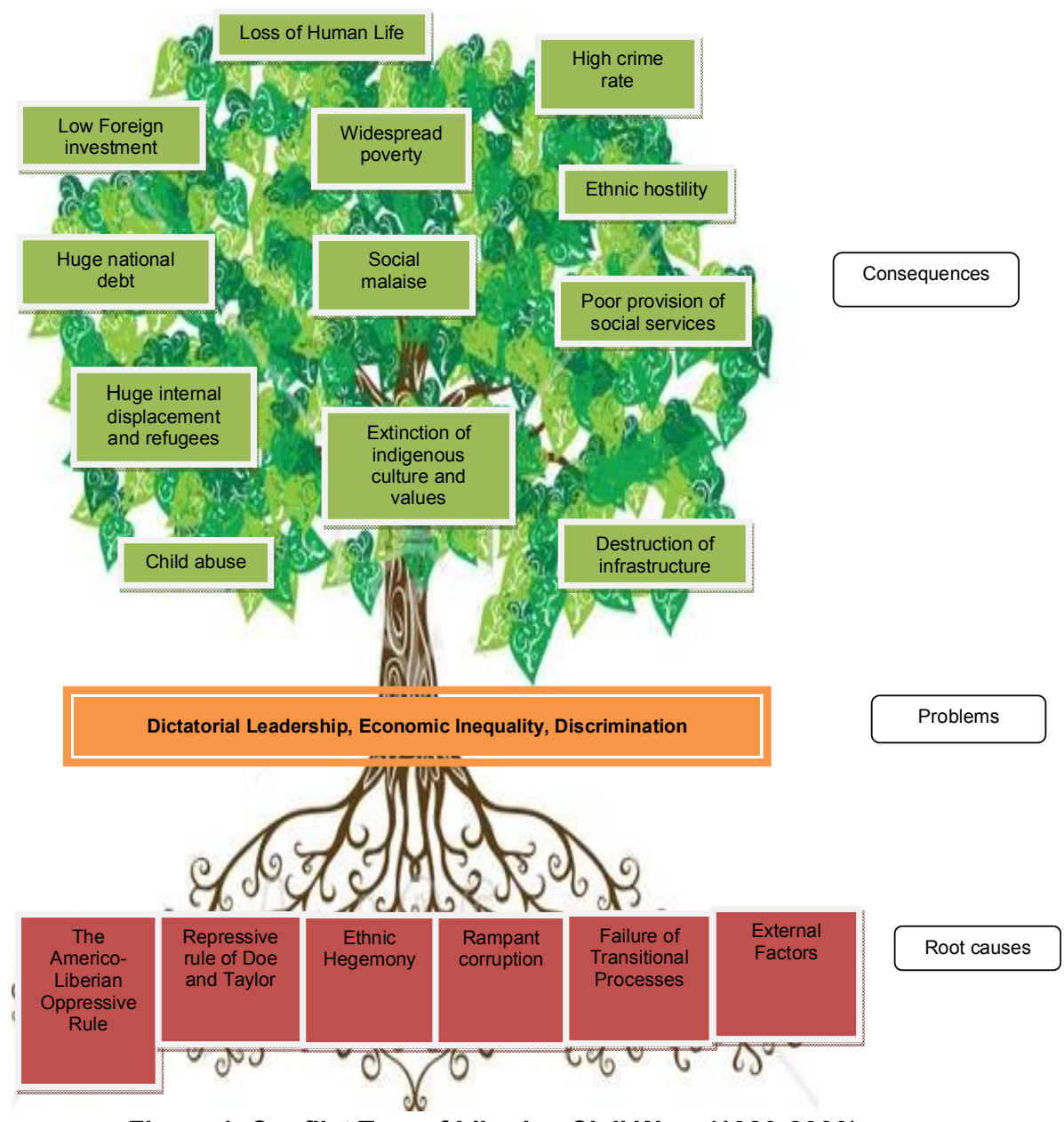

Figure 1. Conflict Tree of Liberian Civil Wars (1989-2003).

\footnotetext{
${ }^{3}$ Liberia Second Civil War 1997-2003. Available at: https://www.globalsecurity.org/military/world/war/liberia-1997.htm. ${ }^{4}$ Ibid.
}

${ }^{5}$ Antiterrorist Unit (ATU). Available at: https://www.globalsecurity.org/military/world/liberia/atu.htm. 
that "as the conflict became more protracted, reports are that ECOMOG soldiers who were underpaid and understaffed entered into deals with warring factions, thus also benefiting from the 'business of war'". This implies that the peacekeeping force was engaged in exploiting resources of Liberia.

\section{Actors of the Civil war}

Different parties with their own interests were involved in the two Liberian civil wars. Broadly, they can be classified as primary, secondary and tertiary actors.

\section{Primary Actors}

The principal actors in the first civil war were political figures, the security forces, as well as other individuals and groups in Doe's administration, the NPFL forces led by Taylor and other warring factions. These parties were fighting for political power, economic gain and social autonomy (The Advocates for Human Rights, 2009; Dick, 2003; Akpan, 1973). Moreover; people from the Krahn, Gio, Mano and Mandingo tribes were involved (The Advocates for Human Rights, 2009; Dick, 2003).

On the other hand; Taylor's administration, opposition groups like the Liberians United for Reconciliation and Democracy (LURD) as well as the Movement for Democracy in Liberia (MODEL) and other warring factions were chief actors in the second civil war (Kieh, 2009) ${ }^{6}$.

\section{Secondary Actors}

Neighboring states like Sierra Leone, Guinea, Burkina Faso, Gambia, Cote d'Ivoire, Nigeria and Ghana were involved in two civil wars for national and regional security reasons (Cook, 2003; Dick, 2003). Nigeria and Ghana were primary contributors of troops for the ECOMOG (Dick, 2003). International actors like the UN, the US and the EU were also involved in issues involving donation, regional security and refugees. The UN also sent a force named the United Nation Observer Mission in Liberia (UNOMIL) in 1997 to monitor the compliance with the ban, support the ECOMOG and render humanitarian assistance (Cook, 2003).

\section{Tertiary Actors}

Different humanitarian organizations like the UNHCR, the USAID, the UNICEF and the International Red Cross were involved in relief works for internally displaced communities and refugees against the poor infrastructure of the country and life-threatening conditions (Cook, 2003) ${ }^{7}$.

\section{Dynamics of the Civil Wars}

The underlying grievances at the systematic exclusion and marginalization of indigenous community due to the Americo-Liberians were voiced openly and resulted in the assassination of President Tolbert in a coup d'état organized by Sergeant Samuel Doe on 12 April 1980, which made the settlers' regime come to an end (Dick, 2003). However, President Doe was unable to solve the fundamental problems of the Liberians.

The fact that Doe was encircled by his own ethnic group - the Krahn, coupled with the repressive ruling, fraudulent results of 1985 election and mass killings of the Gio and Mano tribes, following a coup-attempt on Doe by Quiwonkpa on 1985, deteriorated the legitimacy of the government (Kraaij, 2015; Galvanek, 2016). Finally, on 24 December 1989, the National Patriotic Front of Liberia (NPFL) led by

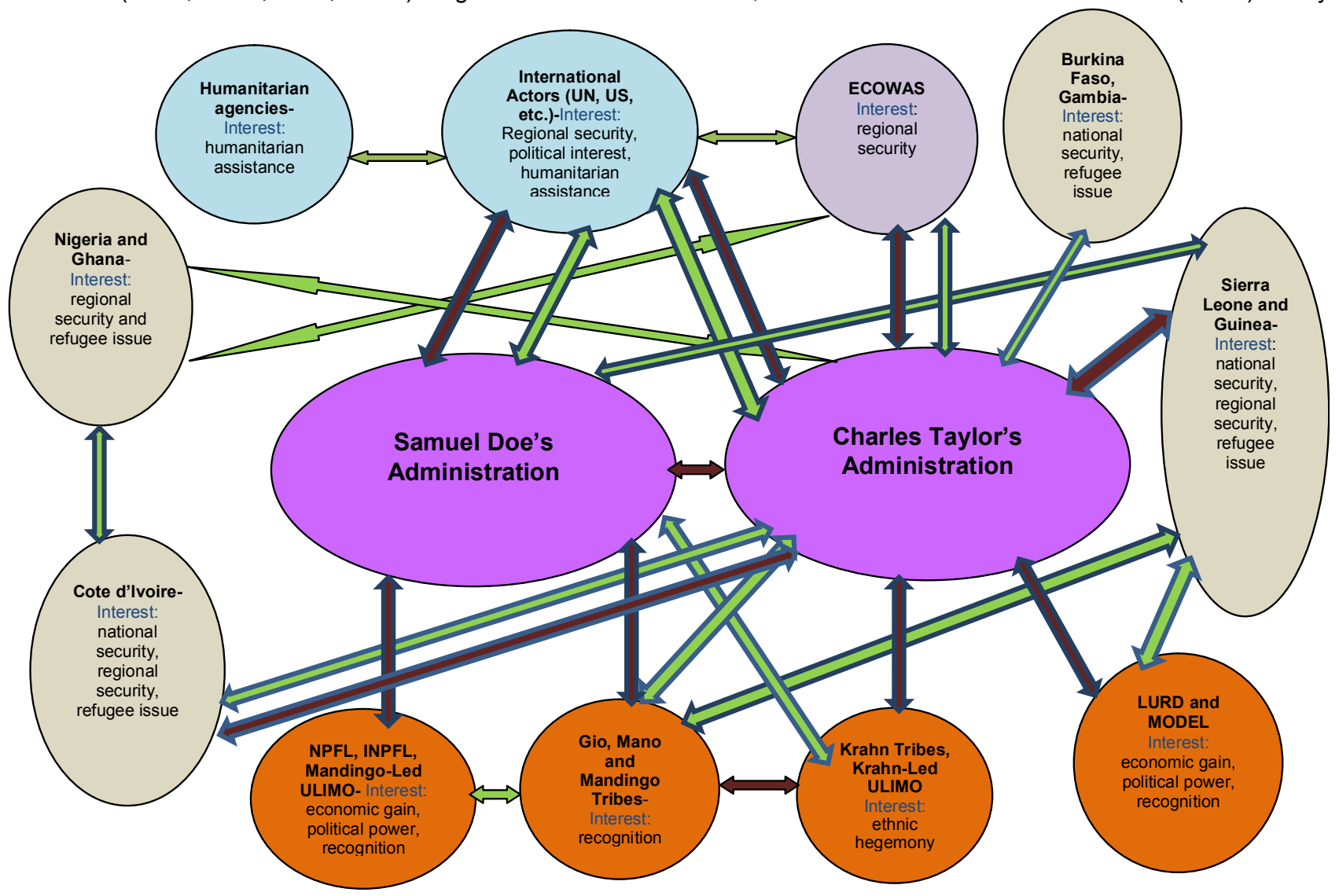

KEY: $\leadsto$ Good relationship $\leadsto$ Conflictual relationship

Figure 2. Conflict Map of Liberian Civil Wars (1989-2003)

${ }^{6}$ Liberia Second Civil War 1997-2003. Available at: https://www.globalsecurity.org/military/world/war/liberia-1997.htm. ${ }^{7}$ Ibid.

СХІД № 6 (158) листопад-грудень 2018 р. 
Charles Taylor launched an attack on the Nimba County (Dick, 2003). This was the beginning of the first Liberian civil war and most of NPFL members were from marginalized tribes - Gio and Mano.

The war was intense with massive bloodshed throughout the 1990s between the Armed forces of Liberia (AFL) and the Krahn tribes on Doe's side, the NPFL with the Gio and Mano tribes, the Johnson-led Independent National Patriotic Front of Liberia (INPFL) of the Gio tribe, the Krahnled United Liberation Movement of Liberia for Democracy (ULIMO) and the Mandingo-led ULIMO ${ }^{8}$.

To stop the atrocities, the ECOWAS formed the ECOMOG in August 1990 to keep law and order in Liberia (Dick, 2003). Though tiresome to get factional leaders in to an agreement, the ECOWAS was able to succeed in the "Abuja Peace Agreement" in 1996, which paved the way for presidential election won by Taylor in 1997 (Galvanek, 2016). The UN also sent the UNOMIL to help the ECOMOG executing the agreement in $1993^{9}$.

In Taylor's terms, however, the failure of transitional processes after the first civil war, repressive actions by the government, violation of cease-fire agreements, the fact that the government as well as rebel leaders relentlessly worked for personal enrichment, unemployment and poverty weakened the position of Liberia instrumentally (Kieh, 2009). Those situations created a fertile ground for insurgencies of the first civil war to strengthen further.

In April 1999, the LURD composed of some ULIMO fighters who were supported by Guinea entered Liberia and started attacking Taylor's government. Other internal opposition groups like the MODEL and other small insurgencies were also created. While Taylor supported the opposition group RUF in fighting the Sierra Leone government, Sierra Leone supported the LURD. The above turned Liberia into a complex war zone and threatened regional security $(\text { Dick, 2003) })^{10}$.

Different national, regional and international interventions have been pursued to end violence and support the victims in Liberia. The 2002 women movement in Liberia, the ECOWAS involvement in peace talks and establishment of the ECOWAS mission in Liberia (ECOMIL) in 2003 as well as peacekeeping efforts by the United Nations Mission in Liberia (UNMIL) in 2003 are noteworthy ${ }^{11}$. What is more the UNHCR, the USAID and other NGOs were involved in relief activities. However there were occasions where they were forced to leave some areas due to looting of their equipment (Cook, 2003).

The UN Security Council also introduced sanctions on arms importation, diamond export and foreign travels of high government officials of Liberia due to Taylor's role in exacerbating the war in Sierra Leone by supporting the RUF in $2001^{12}$. In 2002, the Sierra Leone government and the UN set up a special court to prosecute those responsible for atrocities in the civil war. Consequently, on 4 June 2004, the court issued an arrest warrant for President Taylor to make him responsible for war crimes and crimes against humanity ${ }^{13}$.

\footnotetext{
8 Liberian History. Available at: https://josh-benitone-rf1I. squarespace.com/s/Liberia-History.pdf.

${ }^{9}$ Liberian History. Available at: https://josh-benitone-rf1l.squarespace.com/s/Liberia-History.pdf.

10 Liberia Second Civil War 1997-2003. Available at: https:// www.globalsecurity.org/military/world/war/liberia-1997.htm.

11 Liberian History. Available at: https://josh-benitone-rf1l.squarespace.com/s/Liberia-History.pdf.

12 https://www.globalsecurity.org/military/world/war/liberia1997.htm

13 lbid.
}

Finally, 14 years of civil war that led to the killing of thousands of the Liberians, displacement of millions and annihilation of the most of the country's infrastructure and livelihood of the community ended with the Accra Comprehensive Peace Agreement signed between warring factions on 18 August 2003 in Accra, Ghana. President Taylor stepped down in August 2003 and was brought to a special court in 2006 (Kraaij, 2015). Eventually, the UNMIL and the ECOMIL had been engaged in disarmament, coordinating relief work and peacekeeping till and after Ellen Johnson Sirleaf took power in $2005^{14}$.

\section{Conclusion}

The discussion in this article generally depicts a clear link of the violent conflict developed in Liberia between 1989 and 2003 to historic structures established by the initial colonization of the country by freed slaves from America and then the domination of the country by the AmericoLiberians. The above is then connected to more recent developments and factors, including those at the subregional level. The involvement of parties with opposing views at the local and regional levels intensified the civil unrest to a point where efforts to enumerate displaced local population, refugees and death tolls became tough.

It is to be noted that removal of deep-rooted structural issues of exclusion, marginalization and inequities takes a great deal of time and resources. Unless efforts are made to transform the Liberian socio-political system through democratic reconstruction of the state, it is the belief of the author that the end of the war in 2003 in no guarantee of long lasting peace in Liberia.

\section{REFERENCES}

Akpan, M. B. 1973. Black Imperialism: Americo-Liberian Rule over the African Peoples of Liberia, 1841-1964. Canadian Journal of African Studies, 7(2), 217-236. Available at: https:// www.jstor. org/stable/pdf/483540. pdf? refreqid=excelsior\%3A6962529fc8e114904d3f2c3f285b1ced.

Cook, N. 2003. Liberia: 1989-1997 Civil War, Post-War Developments, and U.S. Relations. Washington: Library of Congress. Available at: https://digital.library.unt.edu/ark:/67531/ metacrs8431/m1/1/high_res_d/RL30933_2003Dec31.pdf.

Country Watch Report. 2018. 2018 Country Review: Liberia. Available at: http://www.countrywatch.com/Content/pdfs/ reviews/B3M8Z8Z9.01C.pdf

Dennis, P. 2006. A Brief History of Liberia. Available at: https:/ /www.ictj.org/sites/default/files/ICTJ-Liberia-Brief-History-2006English.pdf.

Dick, S. 2003. FMO Country Guide: Liberia. Oxford: Refugee Studies Center. Available at: http://www.forcedmigration.org/ research-resources/expert-guides/liberia/fmo013.pdf.

Galvanek, J. B. 2016. Pragmatism and Mistrust: The Interaction of Dispute Resolution Mechanisms in Liberia. Berlin: Berghof Foundation. Available at: https:// www.berghoffoundation.org/fileadmin/redaktion/Publications/ Papers/Liberia_CaseStudy_BF_Report_DSF.pdf.

Gerdes, F. 2013. The Evolution of the Liberian State: A Study in Neo-patrimonial State Formation and Political Change (Working Paper No. 1). Available at: http://edoc.vifapol.de/opus/volltexte/ 2015/5813/pdf/AP_Evolution_State_Gerdes_2013_1.pdf.

Herbert, S. 2014. Conflict Analysis of Liberia. Birmingham, UK: GSDRC, University of Birmingham.

Kieh, G. K. 2009. The Roots of the Second Liberian Civil War. International Journal on World Peace, 26(1), 7-30. Available at: http://www.jstor.org/stable/20752871.

Kieh, G. K. 2012. The "Hegemonic Presidency" and Post-Conflict Peace-building in Liberia. Africa Peace and Conflict Journal. 5(2),

\footnotetext{
${ }^{14}$ Liberian History. Available at: https://josh-benitone-rf1l.squarespace.com/s/Liberia-History.pdf
} 
14-26. Available at: https://onyangorachael.files.wordpress.com/ 2013/01/apcj_vol_5_2_final_web.pdf.

Kraaij, F. 2015. Liberia: From the Love of Liberty to Paradise Lost. Leiden, Holland: African Studies Center. Available at: https:/ /openaccess.leidenuniv. nl/bitstream/handle/1887/33835/ASC075287668-3686-01. pdf? sequence=2.

The Advocates for Human Rights. 2009. A House with Two Rooms: Final Report of the Truth and Reconciliation Commission of Liberia Diaspora Project. Saint Paul, Minnesota: DRI Press. Available at: https://www.theadvocatesforhumanrights.org/ uploads/a_house_with_two_rooms.pdf.

\section{LIST OF REFERENCE LINKS}

Akpan M. B. Black Imperialism: Americo-Liberian Rule over the African Peoples of Liberia, 1841-1964. Canadian Journal of African Studies, 1973. 7(2), 217-236. URL: https://www.jstor.org/ stable/pdf/483540. pdf? refreqid =excelsior\%3A6962529fc8e114904d3f2c3f285b1ced (Accessed: 12.10.2018)

Cook N. Liberia: 1989-1997 Civil War, Post-War Developments, and U.S. Relations. Washington: Library of Congress, 2003. URL: https://digital.library.unt.edu/ark:/67531/metacrs $8431 / \mathrm{m} 1 / 1 /$ high_res_d/RL30933_2003Dec31.pdf (Accessed: 19.09.2018)

Country Watch Report. 2018 Country Review: Liberia. URL: http://www.countrywatch.com/Content/pdfs/reviews/ B3M8Z8Z9.01c.pdf (Accessed: 08.10.2018)

Dennis P. A Brief History of Liberia. 2006. URL: https:// www.ictj.org/sites/default/files/ICTJ-Liberia-Brief-History-2006English.pdf (Accessed: 14.09.2018)

Dick S. FMO Country Guide: Liberia. Oxford: Refugee Studies
Center, 2003. URL: http://www.forcedmigration.org/researchresources/expert-guides/liberia/fmo013.pdf (Accessed: 06.10.2018)

Galvanek J. B. Pragmatism and Mistrust: The Interaction of Dispute Resolution Mechanisms in Liberia. Berlin: Berghof Foundation. 2016. URL: https://www.berghoffoundation.org/ fileadmin/redaktion/Publications/Papers/Liberia_CaseStudy_BF_Report_DSF.pdf (Accessed: 24.09.2018)

Gerdes F. The Evolution of the Liberian State: A Study in Neopatrimonial State Formation and Political Change (Working Paper No. 1, 2013.). URL: http://edoc.vifapol.de/opus/volltexte/2015/ 5813/pdf/AP_Evolution_State_Gerdes_2013_1.pdf (Accessed: 06.10.2018)

Herbert S. ConflictAnalysis of Liberia. Birmingham, UK: GSDRC, University of Birmingham 2014

Kieh G. K. The Roots of the Second Liberian Civil War. International Journal on World Peace, 2009. 26(1), 7-30. URL: http://www.jstor.org/stable/20752871 (Accessed: 13.09.2018)

Kieh G. K. The "Hegemonic Presidency" and Post-Conflict Peace-building in Liberia. Africa Peace and Conflict Journal. 2012. 5(2), 14-26. URL: https://onyangorachael.files.wordpress.com/ 2013/01/apcj_vol_5_2_final_web.pdf (Accessed: 11.10.2018)

Kraaij F. Liberia: From the Love of Liberty to Paradise Lost. Leiden, Holland: African Studies Center. 2015. URL: https:// openaccess.leidenuniv.nl/bitstream/handle/1887/33835/ASC075287668-3686-01. pdf?sequence=2 (Accessed: 09.10.2018)

The Advocates for Human Rights. A House with Two Rooms: Final Report of the Truth and Reconciliation Commission of Liberia Diaspora Project. Saint Paul, Minnesota: DRI Press. 2009. URL: https://www.theadvocatesforhumanrights.org/uploads/ a_house_with_two_rooms.pdf (Accessed: 07.10.2018)

Волдетсадік Мессаш Кассає,

Інститут досліджень миру та безпеки (IPSS),

Університет Аддіс-Абеби (Ефіопія),

e-mail: messashkassaye@gmail.com, ORCID 0000-0003-3590-6198

\section{АНАЛІЗ ВИТОКІВ КОНФЛІКТУ ЛІБЕРІЙСЬКИХ ГРОМАДЯНСЬКИХ ВІЙН (1989-2003)}

У статті відображено результати дослідження, присвяченого вивченню низки громадянських війн у Ліберії 1989-2003 рр. Розглянуто історіографічний доробок та представлено основні наукові підходи до аналізу подій. Автором проаналізовано історичне підґрунтя та передумови виникнення збройного протистояння. Зокрема, наголошується на комплексі причин історико-політичного характеру, 3-поміж яких виділяється: штучність політичних традицій, які були привнесені у XIX ст. переселенцями з США, слабкий розвиток демократичних інституцій та ліберійського суспільства в цілому. Апелюючи до особливостей політичного розвитку у другій половині XX ст., автор представляє нарис протистояння між різними етнічними групами Ліберії. Зазначено, що ключовими факторами нестабільності в державі стали: авторитарні методи управління, високий рівень корупції, надзвичайно низький рівень освіти, неефективна економіка.

Окремо наголошено на тому, що політичний режим президента Вільяма Табмена (1944-1971 рр.) був спрямований на руйнування традиційної соціально-економічної структури корінного населення. За часів президентства Вільяма Табмена широко використовувалися дискримінаційні підходи та політика заміщення ключових постів виключно представниками американо-ліберійської еліти. Політика "відкритих дверей" для американського капіталу, започаткована 3 1920-х років, набула ще більших масштабів при президенті Вільямі Толберті, який продовжив політику попередника. Наприкінці 1970-х років економічне становище в країні почало погіршуватись, а зростання цін на харчові продукти призвело до низки заколотів по всій країні. Апогеєм громадянської непокори стали масові страйки, які призвели до державного перевороту 1980 року. Під час подій 1980 року режим президента Вільяма Толберті був повалений. Влада в країні перейшла до одного 3 лідерів етнічної групи Кран - Самуеля Доу, який стратив президента та всю управлінську верхівку. Друга половина 1980-х років стала часом транзиту влади й заміщення ключових посад представниками етнічної групи Кранів.

Саме у подіях, дотичних до формування нового альянсу політичних сил, представлених численними представниками корінного населення, створювалися найбільші протиріччя режиму, до яких згодом додалися й зовнішні актори - Сьєра Леоне та США.

Комплекс протиріч, сформований в країні та інтереси учасників протистояння візуалізовано у двох матрицях, які відбивають авторську концепцію розуміння рушійних сил та витоків низки громадянських війн у Ліберії.

Ключові слова: Ліберія; конфрлікт; громадянська війна; конфрліктуючі сторони; перебіг; динаміка.

(c) Messash Kassaye Woldetsadik

Надійшла до редакції: 13.09.2018

Прийнята до друку: 17.12.2018

СХІД № 6 (158) листопад-грудень 2018 р. 